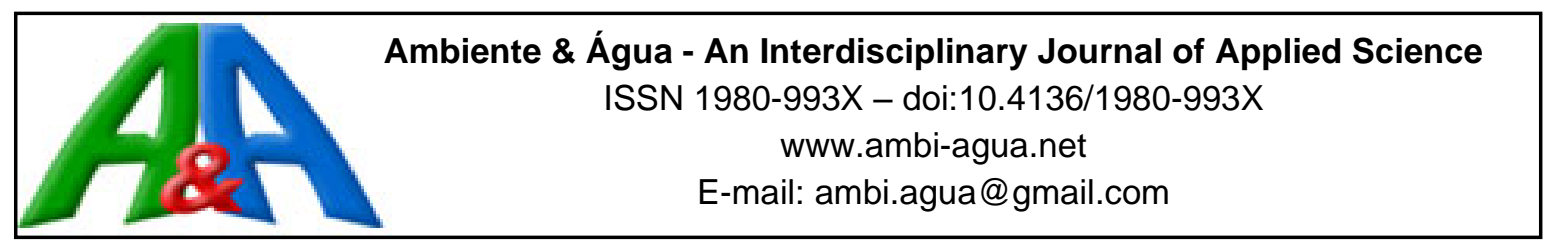

\title{
Coagulation Activity of the Seed Extract from Zygia cauliflora (WILLD.) KILLIP applied in Water Treatment
}

\author{
ARTICLES doi:10.4136/ambi-agua.2611
}

Received: 29 Jun. 2020; Accepted: 28 Sep. 2020

\begin{abstract}
Julia Aoki Domingues ${ }^{1}$; Nelson Consolin Filho ${ }^{2 *}$;
Luiz Augusto Gomes de Souza ${ }^{3}$; Flávia Vieira da Silva Medeiros ${ }^{1}$ (D)
${ }^{1}$ Departamento de Engenharia Ambiental. Universidade Tecnológica Federal do Paraná (UTFPR), Via Rosalina Maria dos Santos, n 1233, CEP: 87301-899, Campo Mourão, PR, Brazil.
E-mail: juaoki12@gmail.com, flaviav@utfpr.edu.br
${ }^{2}$ Departamento de Química. Universidade Tecnológica Federal do Paraná (UTFPR), Via Rosalina Maria dos Santos, $\mathrm{n}^{\circ}$ 1233, CEP: 87301-899, Campo Mourão, PR, Brazil.

${ }^{3}$ Departamento de Ciências Agronômicas. Instituto Nacional de Pesquisas da Amazônia (INPA), Avenida André Araújo, n² 2936, CEP: 69083-000, Manaus, AM, Brazil. E-mail: souzalag@inpa.gov.br

*Corresponding author. E-mail: consolin@utfpr.edu.br
\end{abstract}

\begin{abstract}
The use of natural coagulants is a promising alternative to replace or assist chemical coagulants due to its numerous advantages. This paper evaluates the effectiveness of a natural coagulant in water treatment. The coagulant was extracted from the Zygia cauliflora (Willd.) Killip seed in saline solutions and defatted using $95 \%$ ethanol. The tests were conducted using different concentrations of the coagulant $\left(0.1,0.5,1.0,2.0,3.0\right.$, and $\left.4.0 \mathrm{~g} \mathrm{~L}^{-1}\right)$ and of $\mathrm{NaCl}(0.0$ $\mathrm{M}, 1.0 \mathrm{M}$, and $5.0 \mathrm{M})$. The results showed that the use of $2 \mathrm{~g} \mathrm{~L}^{-1}$ of coagulant and $1.0 \mathrm{M}$ of the salt achieved an effectiveness of $20 \%$ and $70 \%$, respectively, of color and turbidity removal. The analysis showed an effectiveness of $70 \%$ and $30 \%$, respectively, when removing the $\mathrm{UV}_{254}$ compound and DOM (dissolved organic matter). The mechanism for turbidity removal by the coagulants prepared with aqueous solution and with saline solution at $1.0 \mathrm{M}$ of $\mathrm{NaCl}$ is supposed to be adsorption and charge neutralization, respectively, following the Freundlich and Langmuir models. However, the coagulant prepared with saline solution at $5.0 \mathrm{M}$ of $\mathrm{NaCl}$ tends to form a netlike structure followed by turbidity removal through a sweep coagulation mechanism. Future papers should therefore focus on the use of Zygia cauliflora (Willd.) Killip as an alternative for replacement or use as an auxiliary chemical coagulant.
\end{abstract}

Keywords: Amazon seed, flocculation, natural coagulant.

\section{Atividade Coagulante do Extrato de Sementes de Zygia cauliflora (WILLD.) KILLIP no Tratamento de Água}

\section{RESUMO}

O uso de coagulantes naturais é uma alternativa promissora para substituir ou auxiliar coagulantes químicos devido às suas inúmeras vantagens. Este artigo avalia a eficácia no uso de um coagulante natural no tratamento de água. O coagulante foi extraído da semente de Killip Zygia cauliflora (Willd.) em soluções salinas e desengordurada com etanol a 95\%. Os testes foram conduzidos utilizando diferentes concentrações do coagulante $(0,1,0,5,1,0,2,0,3,0$ e 
4,0 $\left.\mathrm{g} \mathrm{L}^{-1}\right)$ e de $\mathrm{NaCl}\left(0,0 \mathrm{M}, 1,0 \mathrm{M}\right.$ e 5,0 M). Os resultados mostraram que o uso de $2 \mathrm{~g} \mathrm{~L}^{-1}$ de coagulante e 1,0 M de sal alcançou uma eficácia de $20 \%$ e $70 \%$, respectivamente, na remoção de cor e turbidez. A análise mostrou uma eficácia de $70 \%$ e $30 \%$, respectivamente, na remoção do composto UV254 e DOM (matéria orgânica dissolvida). Além disso, o mecanismo de remoção da turbidez pelos coagulantes preparados com solução aquosa e com solução salina a 1,0 M de $\mathrm{NaCl}$ é suposto ser adsorção e neutralização de carga, respectivamente seguindo os modelos de Freundlich e Langmuir. No entanto, o coagulante preparado com solução salina a 5,0 M de $\mathrm{NaCl}$ tende a formar uma estrutura semelhante a uma rede seguida pela remoção da turbidez por mecanismo de coagulação por varredura. Portanto, trabalhos futuros devem se concentrar no uso de Zygia cauliflora (Willd.) Killip como uma alternativa para substituição ou uso como coagulante químico auxiliar.

Palavras-chave: coagulante natural, floculação, semente da Amazônia.

\section{INTRODUCTION}

According to the World Health Organization (WHO) and its member countries, "every person, at any stage of development and socio-economic conditions, has the right to access an adequate supply of potable and safe water'. In this context, 'safe' refers to a water supply which does not represent a health risk, with enough quantity to meet all household needs, that is continuously available, and is affordable. If the purpose is to improve public health, such conditions must be considered when defining and maintaining water quality and water supply programs (OPS, 2001).

During the water treatment process, one of the first steps is coagulation, which aims to reduce impurities to make the water potable. Since it is a delicate part of the treatment, a strict control of the dosage of these chemical products is necessary. However, an increase of these dosages is required considering the high demand of potable water and a considerable decrease in the quality of water resources. The decision of coagulant is often based on economic factors, related to suitability, raw water, treatment technology, and cost (Richter et al., 1991).

According to Richter (2009), the most commonly used coagulants are iron and aluminumbased coagulants, due to their reaction with the natural alkalinity of raw water. According to several studies, there is evidence of a relationship between the content of aluminum in treated water and the increasing incidents of neurological diseases. According to Flaten (2001), aluminum plays an important role in the etiology and pathogenesis of Alzheimer's, but this connection is still under debate. Bondy (2010) states that there are analyses that link Parkinson's disease and other chronic neurodegenerative diseases as well.

Moreover, the high sensitivity of inorganic coagulants to the water $\mathrm{pH}$ and the possibility of secondary contamination of drinking water with traces of toxic synthetic polymeric coagulants or residual iron and aluminum ions are the main challenges for flocculationcoagulation water treatment processes (Bratskaya et al., 2004).

In view of these disadvantages, it is desirable to replace chemical coagulants with natural coagulants. Using natural plants as coagulants has many advantages, among which are their profitability, biodegradability, and lack of requirement for a high $\mathrm{pH}$ for water treatment (Bratskaya et al., 2004).

Thus, the Moringa oleifera Lam (moringa) seed has been gaining prominence as a natural coagulant in water treatment since the species contains an edible oil, a water-soluble substance with protein in its organic composition, and can act as an effective coagulant Salazer Gámez et al., 2015). However, Moringa oleifera is an Indian seed, so its availability could be restrictive for water treatment worldwide. It is therefore important to research the applicability of regional leguminous seeds that could play the same role as Moringa oleifera Lam. 
Many plants have recently been identified as sources of natural polymers for the treatment of various types of water, including Plantago ovata, Musa ABB, and Strychnos potatorum (Ramavandi, 2014; Tirado et al., 2017; Gaikwad and Munavalli, 2019).

The use of regional coagulants is studied to evaluate their applicability regarding the difference in coagulation capacity, cheapness, variety, and ease of access. This research has attempted to use Zygia cauliflora (Willd.) Killip. seeds as an abundantly available, low-cost, and renewable precursor for producing a coagulant for improving water quality. Zygia cauliflora (Willd.) Killip. was considered because it is one of the most abundant species in undisturbed forests and with the highest density throughout the Amazon rainforest, especially in permanent preservation areas of the Moju River Basin (Oliveira et al., 2016). Zygia cauliflora (Willd.) Killip. trees, flowers and seeds are shown in Figure 1.

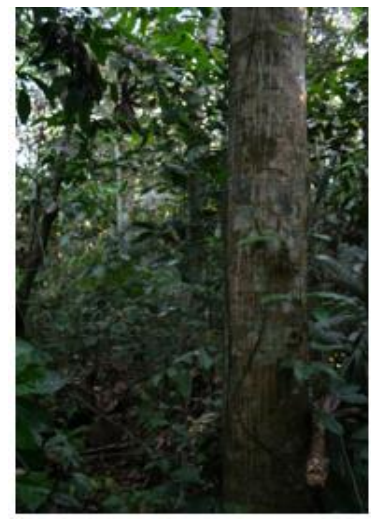

(a)

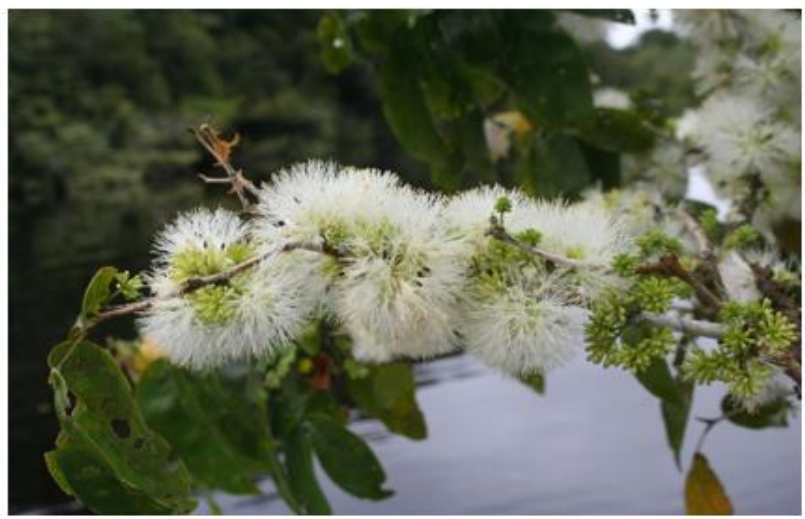

(b)

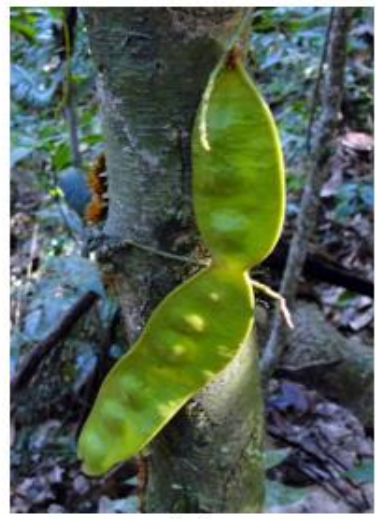

(c)

Figure 1. Zygia cauliflora (Willd.) Killip. tree (a), flowers (b) and seeds (c).

Therefore, this paper evaluates the coagulation potential of aqueous and saline solutions obtained from Zygia cauliflora (Willd.) Killip. seeds to determine water color, turbidity, and organic compounds absorbed at $254 \mathrm{~nm}$ ( $\mathrm{UV}_{254}$ compounds) and to remove dissolved organic matter (DOM). The effect of the operational parameters including coagulant dosage and $\mathrm{NaCl}$ concentration was studied to better understand the coagulation process using Zygia cauliflora (Willd.) Killip. seeds.

\section{MATERIALS AND METHODS}

Raw water samples were collected from a public water treatment system (WTS), Paraná Sanitation Company (Companhia de Saneamento do Paraná, SANEPAR), located in Campo Mourão, State of Paraná, Brazil. The surface water originates from the Campo River Basin.

Characterization before and after the treatment was carried out using quality parameters such as color, turbidity, $\mathrm{UV}_{254}$, and dissolved organic matter (DOM). 


\subsection{Color}

The apparent color was determined based on the procedures described in Standard Methods for the Examination of Water and Wastewater ${ }^{10}$ using the Digimed colorimeter equipment, Model DM-COR.

\subsection{Turbidity}

The turbidity was determined based on the procedures described in Standard Methods for the Examination of Water and Wastewater (APHA et al., 2012) using a turbidimeter (PoliControl equipment, Model AP2000 iR).

\subsection{Dissolved organic matter parameters}

The $\mathrm{UV}_{254}$ and $\mathrm{UV}_{272}$ compounds were determined using the $\mathrm{HACH}$ spectrophotometer, Model DR5000.

Equation 1 was used to determine the concentration of dissolved organic matter from $\mathrm{UV}_{272}$ results, a method proposed previously (Khan et al., 2014).

$$
\operatorname{DOM}\left(\mathrm{mg} \mathrm{L}^{-1}\right)=518.93 \times \text { Absorbance }(272 \mathrm{~nm})+1.065
$$

The detection of dissolved organic matter (DOM) in water is necessary since it consists of a set of substances originated from the excretion, secretion, and intermediary process of the decomposition of terrestrial and aquatic organisms (Di Bernardo et al., 2002), which influences water appearance among other consequences.

\subsection{Extraction and preparation of the coagulant}

The method used for the extraction and preparation of the coagulant in saline solution was described by Sánchez-Martín et al. (2010).

The peels of the Zygia cauliflora (Willd.) Killip seeds were manually removed and ground in a domestic blender. The powder was defatted in $95 \%$ ethanol with a mass/volume ratio of 1:10 using a magnetic stirrer for 45 minutes at $150 \mathrm{rpm}$.

The supernatant was manually separated and placed in glass tubes so that the resulting powder would dry in an oven at $60^{\circ} \mathrm{C}$ for three days.

A coagulant was prepared in distilled water, which was denominated aqueous solution. One gram of the dried seed was added in a glass beaker containing $0.1 \mathrm{~L}$. The coagulant was extracted by turbolysis for 3 minutes and then stirred in a magnetic stirrer for 30 minutes at 150 $\mathrm{rpm}$. The obtained solution was vacuum filtrated on quality filter paper and then on a $0.9 \mu \mathrm{m}$ pore glass fiber membrane. The dried seeds and turbolysis process are shown in Figure 2.

The same procedure was performed for the saline solutions of $1 \mathrm{M}$ and $5 \mathrm{M}$.

All tests were performed in duplicate.
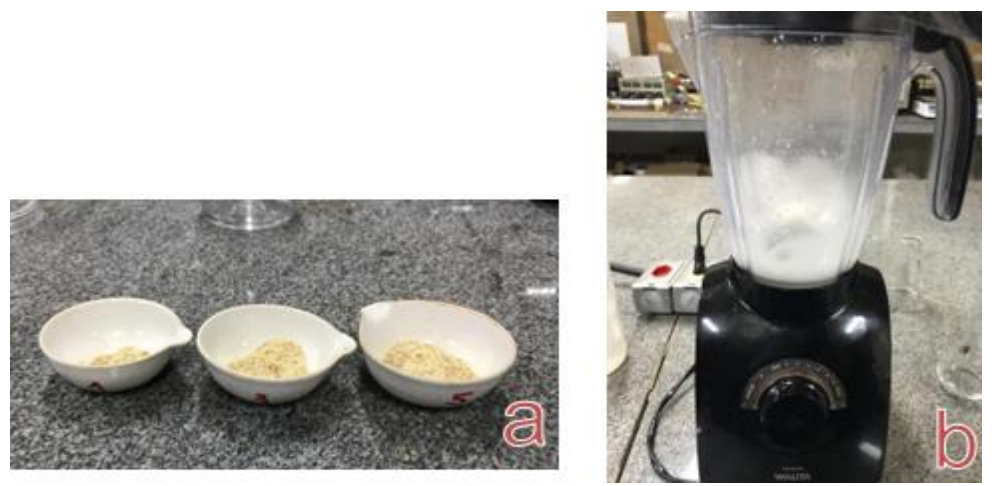

Figure 2. Dried seeds (a) and turbolysis process (b). 


\subsection{Coagulation/flocculation test}

The coagulation/flocculation tests were performed on a Jar test device (Nova Ética) with a rotating regulator of mixing rods and jars with capacity of $1 \mathrm{~L}$ (Figure 3 ).

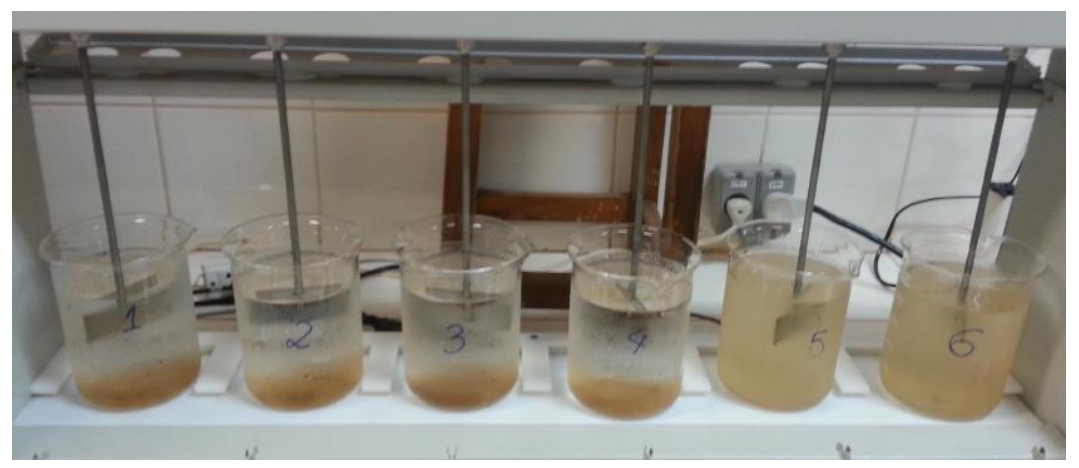

Figure 3. Coagulation/flocculation performed on Jar test equipment.

The use of the Jar Test allows the determination of the ideal dosage of coagulant or coagulation aid necessary to cause raw water clarification (Di Bernardo et al., 2002).

Predetermined amounts of coagulant solution were added to each jar (Table 1), using an automatic pipette. The water used was at room temperature, without any $\mathrm{pH}$ correction or adjustment.

Table 1. Coagulant concentration solution in each jar.

\begin{tabular}{lcccccc}
\hline & Jar 1 & Jar 2 & Jar 3 & Jar 4 & Jar 5 & Jar 6 \\
\hline Coagulant concentration $\left(\mathrm{mg} \mathrm{L}^{-1}\right)$ & 0.1 & 0.5 & 1.0 & 2.0 & 3.0 & 4.0 \\
\hline
\end{tabular}

The rapid mixing was set at 1 minute, with gradient speed of $120 \mathrm{rpm}$, while the slow mixing was set at 15 minutes at $60 \mathrm{rpm}$. The settling time was established at 15 minutes. The methodology used for the tests was described in Di Bernardo et al. (2002).

Subsequently, the color, turbidity, $\mathrm{UV}_{254}$ compounds, and DOM were measured to verify the efficiency of the process by comparing the results with raw water.

\subsection{Mechanism evaluation}

In order to evaluate the mechanism of coagulation/flocculation process using aqueous and saline solutions obtained from Zygia cauliflora (Willd.) Killip, Langmuir and Freundlich isotherms were employed to describe adsorption equilibrium. This evaluation was performed using turbidity removal data and was adapted from Fahmi et al. (2011), Mateus et al. (2020), Zhou et al. (2018) and Sia et al. (2020).

The theoretically derived Langmuir model assumes adsorption energies are uniform and independent of surface coverage and complete coverage of surface by a monolayer of adsorbate indicates maximum adsorption. The linear form of Langmuir isotherm is given in Equation 2:

$\frac{1}{q_{e}}=\frac{1}{q_{m}}+\frac{1}{q_{m} K_{l} C_{e}}$

Where:

$\mathrm{q}_{\mathrm{e}}=$ ratio of turbidity adsorbed to the dosage of coagulant employed

$\mathrm{C}_{\mathrm{e}}=$ equilibrium concentration of turbidity

$\mathrm{q}_{\mathrm{m}}=$ maximum adsorption capacity of the coagulant employed

$\mathrm{K}_{\mathrm{l}}=$ Langmuir constant, related to the energy of adsorption 
The value of Langmuir constants (slope) and maximum adsorption capacity (intercept) were obtained from the linear correlation plots between $1 / q_{\mathrm{e}}$ with $1 / \mathrm{C}_{\mathrm{e}}$.

On the other hand, the Freundlich model is empirical, encompassing the heterogeneity of adsorbent surface, the exponential distribution sites and their energies. The linear equation of the Freundlich isotherm is given in Equation 3:

$l q_{e}=l K_{f}+\frac{1}{n} l C_{e}$

Where:

$\mathrm{q}_{\mathrm{e}}=$ ratio of turbidity adsorbed to the dosage of coagulant employed

$\mathrm{C}_{\mathrm{e}}=$ equilibrium concentration of turbidity

$\mathrm{K}_{\mathrm{f}}=$ Freundlich constant indicative of the relative adsorption capacity of the adsorbent

$1 / \mathrm{n}=$ constant that indicates the adsorption intensity

The value of Freundlich constants (slope) and adsorption intensity (intercept) were obtained from the linear correlation plots between $\ln \mathrm{q}_{\mathrm{e}}$ with $\ln \mathrm{C}_{\mathrm{e}}$.

\section{RESULTS AND DISCUSSION}

\subsection{Characterization of the raw water}

The results of the raw water characterizations are presented in Table 2 according to color, turbidity, $\mathrm{UV}_{254}$ compounds, and DOM.

Table 2. Results of the physical-chemical analysis of the raw water.

\begin{tabular}{cc}
\hline & Raw water \\
\hline Color (uH) & 92.2 \\
Turbidity (NTU) & 76.3 \\
$\mathrm{UV}_{254}(\mathrm{abs})$ & 1.367 \\
DOM $\left(\mathrm{mg} \mathrm{L}^{-1}\right)$ & $1,183.2$ \\
\hline
\end{tabular}

According to Gaikwad et al. (2019), the composition of typical raw water samples collected from a river has a turbidity of 5-50 NTU. The turbidity of the raw water collected in this study was 76.3 NTU, which can be considered high.

On the other hand, the raw water characteristics are similar to reports found in literature. Ramavandi (2014) evaluated a coagulant extracted from Platago ovata and used a raw water with turbidity of $76 \mathrm{NTU}$, TOC (total organic carbon) of $8.6 \mathrm{mg} \mathrm{L}^{-1}$ and DOC of $4.02 \mathrm{mg} \mathrm{L}^{-1} .8$ Lima et al. (2017) used raw water with color of 174 UC and turbidity of 97 NTU when studying Abelmoschus esculentus as a flocculation aid. Malik (2018) used raw water with higher levels of turbidity, 250 NTU.

\subsection{Results of the tests with Zygia cauliflora (Willd.) Killip as a potential natural coagulant}

Figure 4 presents the results of color, turbidity, $\mathrm{UV}_{254 \mathrm{~nm}}$ absorption compounds, and DOM removal obtained with the coagulants prepared from Zygia cauliflora (Willd.) Killip in different dosages and different concentrations of $\mathrm{NaCl}$. The results with saline solutions were similar, showing no considerable variations between 1.0 M and 5.0 M solutions. The results of removing 
the color, turbidity, and $\mathrm{UV}_{254}$ were approximately $20 \%, 70 \%$, and $70 \%$, respectively, with no considerable differences between the dosage employed. Despite this, the coagulant prepared with $5.0 \mathrm{M}$ of $\mathrm{NaCl}$ removed no DOM at any dosage, while the coagulant prepared with $1.0 \mathrm{M}$ of $\mathrm{NaCl}$ removed approximately $21 \%$ of DOM at all dosages.

On the other hand, the coagulant obtained from the aqueous solution removed no color, while removing turbidity, $\mathrm{UV}_{254}$, and DOM at approximately $45 \%, 70 \%$, and 30\%, respectively.

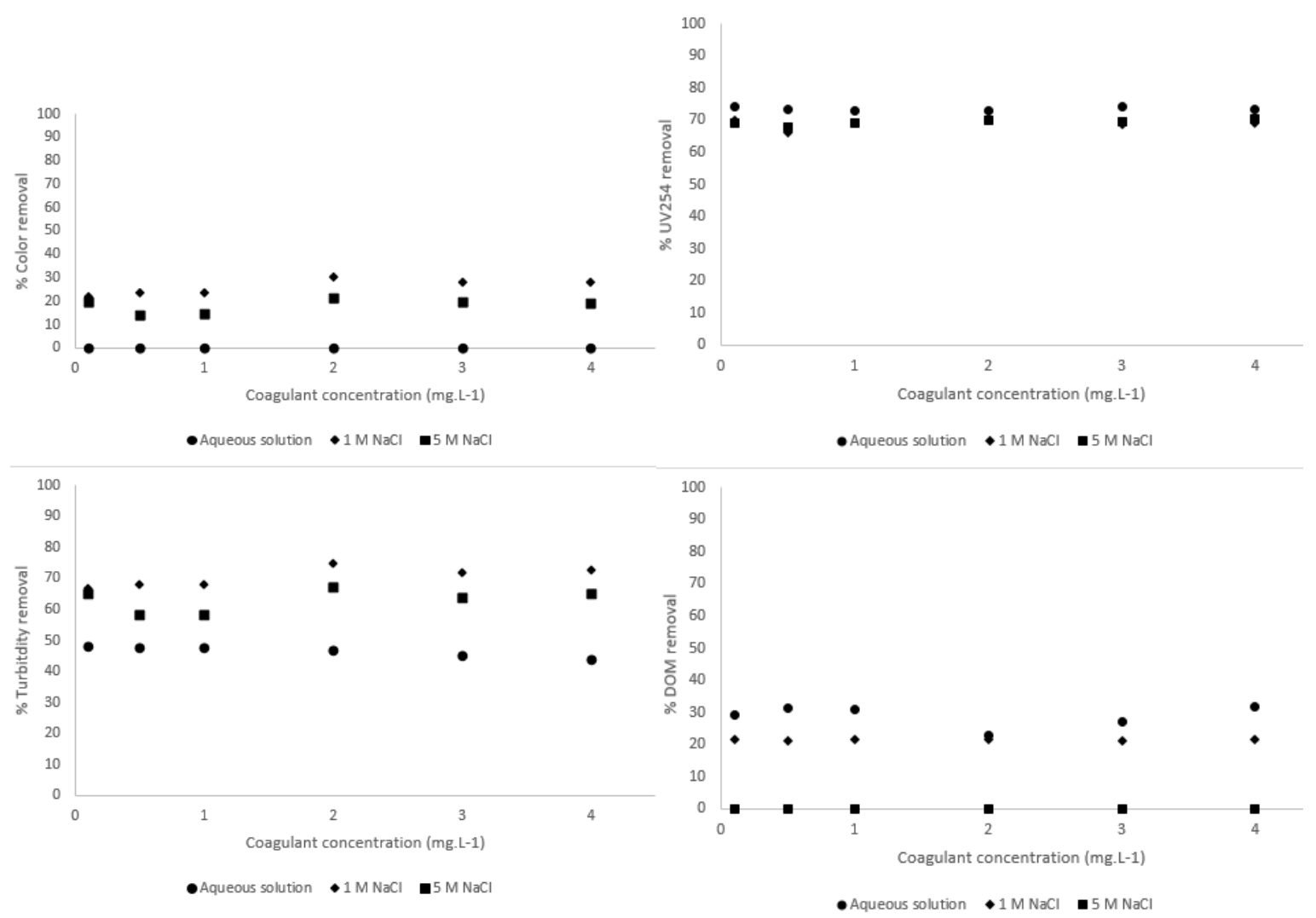

Figure 4. Efficiency of removal of parameters using different dosages of coagulants prepared from Zygia cauliflora (Willd.) Killip.

Considering these results, the coagulants prepared with a saline solution at $1.0 \mathrm{M}$ of $\mathrm{NaCl}$ were more efficient than those prepared with a $5.0 \mathrm{M}$ solution. Furthermore, better results were obtained for the coagulant concentration of $2 \mathrm{~g} \mathrm{~L}^{-1}$, even when compared to concentrations of $3 \mathrm{~g} \mathrm{~L}^{-1}$ and $4 \mathrm{~g} \mathrm{~L}^{-1}$, which also showed reasonable results of color and turbidity removal. Thus, a more satisfactory efficiency was obtained for the saline solution with $1.0 \mathrm{M}$ concentration of $\mathrm{NaCl}$ for the analyzed parameters, presenting $30.4 \%$ and $74.5 \%$ of removal, respectively, for color and turbidity.

Moreover, the saline solutions presented greater efficiency in removing color and turbidity when compared with the aqueous solution, as observed by Madrona et al. (2010), Nkurunziza et al. (2009), and Nishi et al. (2011).

Nkurunziza et al. (2009) reached $99.8 \%$ of turbidity removal using Moringa oleifera coagulant extracted with saline solution at $1.0 \mathrm{M}$, while Nishi et al. (2011) obtained $96.4 \%$ of color removal in the same conditions. These results suggest that Zygia cauliflora (Willd.) Killip could be applied as a coagulation/flocculation aid, instead of a primary coagulant.

The aqueous solution presented better $\mathrm{UV}_{254}$ compound and DOM removal, removing $74.3 \%$ of $\mathrm{UV}_{254}$ compounds at the concentration of $3.0 \mathrm{mg} \cdot \mathrm{L}^{-1}$ and $31.7 \%$ of DOM at the concentration of $4.0 \mathrm{mg} \mathrm{L}^{-1}$.

The presence of $\mathrm{NaCl}$ in the water showed that increasing the ionic strength results in a greater amount of extracted compounds, but does not affect coagulation activity, which can be 
observed in the results of $U_{254}$ and DOM removal (Kukic et al. 2015).

Previous work found in the literature shows that the coagulant obtained from Plantago ovata at a dosage of $0.250 \mathrm{mg} \mathrm{L}^{-1}$ showed turbidity removal of $36 \%$ and $99 \%$, respectively, when using crude and treated extract (Ramavandi, 2014).

Tirado et al. (2017) applied higher dosages (5-200 $\mathrm{mg} \mathrm{L}^{-1}$ ) of starch obtained from Musa ABB as a coagulant and achieved color and turbidity removals from 90 to $99 \% .{ }^{9}$ The difference in results when compared to this work could be due to the higher dosages used by the authors.

Valverde et al. (2018) evaluated the synergistic effect between Moringa oleifera and APC (aluminum polychloride) for coagulation/flocculation and observed lower removal efficiencies at greater proportions of moringa, with $70.1 \%, 75.1 \%$, and $56.7 \%$ for color, turbidity, and $\mathrm{UV}_{254}$ absorption, respectively, which suggests that natural coagulants present lower removal efficiencies. Furthermore, Valverde et al. (2018) obtained a turbidity removal close to that observed in this work with the coagulant prepared with saline solutions, from 65 to $70 \%$. Moreover, the removal of $\mathrm{UV}_{254}$ compounds achieved in this paper are higher, at $70 \%$, for aqueous and saline solutions than the results observed by Valverde et al. (2018), even though the authors employed a synthetic coagulant in association with Moringa oleifera.

\subsection{Mechanism evaluation results}

Figures 5 and 6 show the respective results of Langmuir and Freundlich adsorption equilibrium models for turbidity removal, and Table 3 presents the $\mathrm{R}^{2}$ obtained for each model and coagulant condition.

It was observed that the coagulants prepared with aqueous solution and with a saline solution at $1.0 \mathrm{M}$ of $\mathrm{NaCl}$ show positive correlation with Langmuir and Freundlich models. The coagulant prepared in aqueous solution presented $\mathrm{R}^{2}$ of 0.77 and 0.98 , respectively, for the Langmuir and Freundlich models, while the coagulant prepared with a saline solution at $1.0 \mathrm{M}$ of $\mathrm{NaCl}$ showed $\mathrm{R}^{2}$ of 0.63 for and 0.54 , respectively, for the Langmuir and Freundlich models. This indicates that adsorption and charge neutralization mechanisms are most likely involved in the processes (Fahmi et al., 2011).
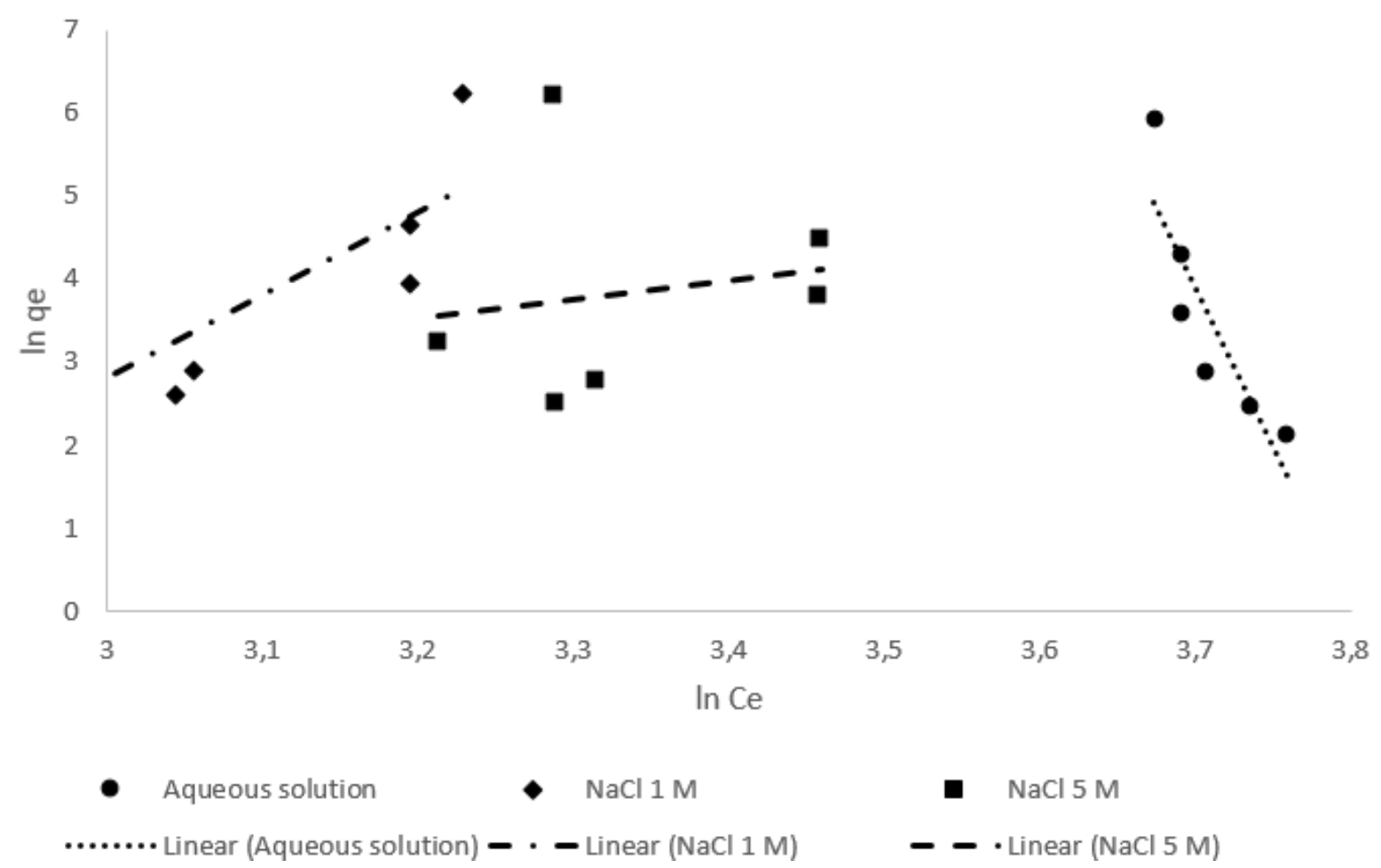

Figure 5. Langmuir adsorption isotherm for turbidity removal. 


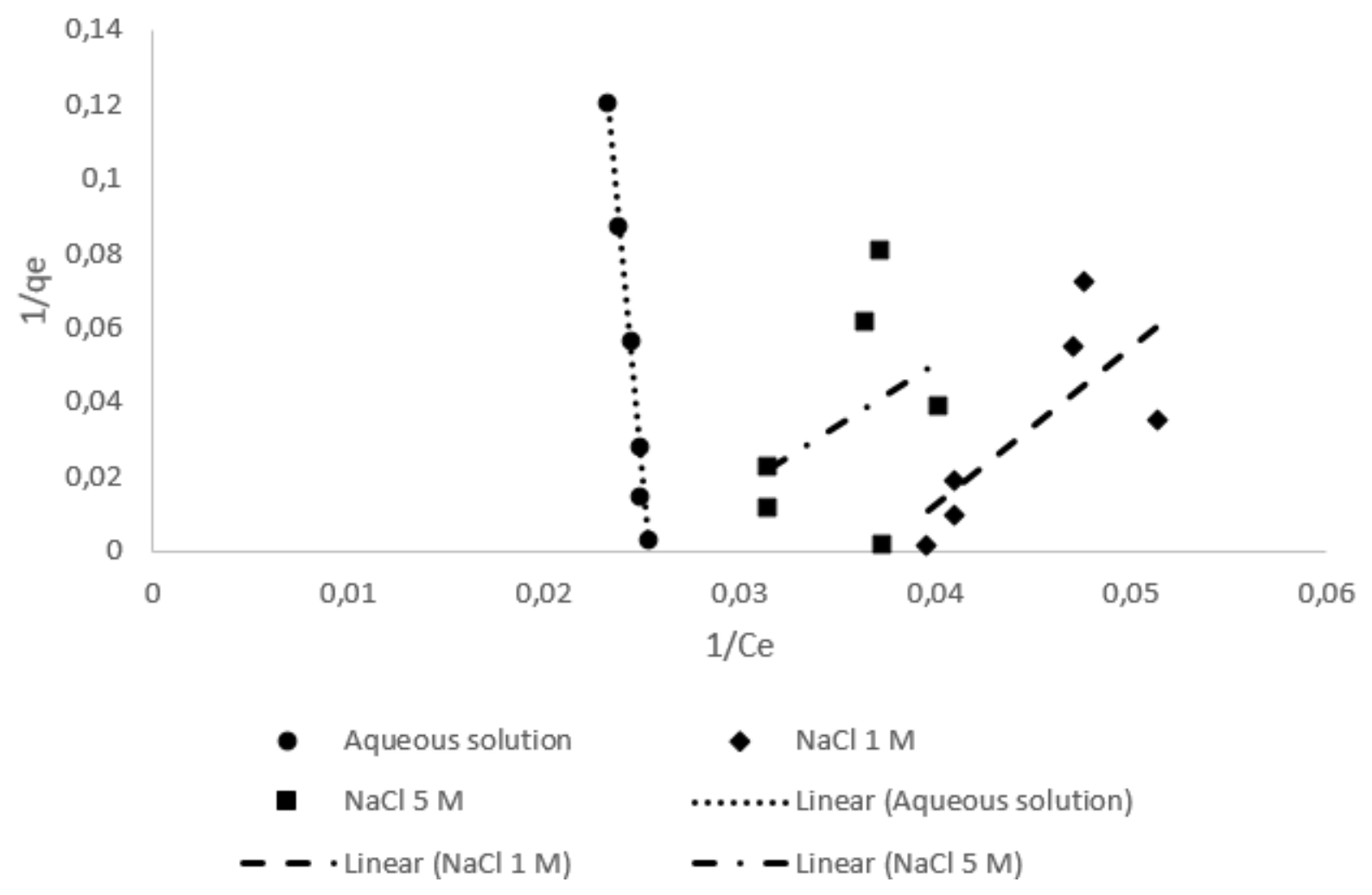

Figure 6. Freundlich adsorption isotherm for turbidity removal.

Table 3. $\mathrm{R}^{2}$ results for Langmuir and Freundlich models applied to turbidity removal.

\begin{tabular}{ccc}
\hline Coagulant condition & $\mathbf{R}^{\mathbf{2}}$ (Langmuir) & $\mathbf{R}^{\mathbf{2}}$ (Freundlich) \\
\hline Aqueous solution & 0.77 & 0.98 \\
$\mathrm{NaCl} \mathrm{1} \mathrm{M}$ & 0.63 & 0.54 \\
$\mathrm{NaCl} \mathrm{5} \mathrm{M}$ & 0.03 & 0.15 \\
\hline
\end{tabular}

Furthermore, the mechanism for turbidity removal for the coagulant obtained from Zygia cauliflora (Willd.) Killip. Extract in aqueous solution was found to be due to adsorption, approximating to the Freundlich type $\left(>R^{2}\right)$, which indicates that adsorption occurs on heterogeneous surface and the adsorption energy decreases logarithmically, as the surface of adsorbent becomes covered by the solute (Fahmi et al., 2011; Mateus et al., 2020; Zhou et al., 2018; Sia et al., 2020).

With the experimental data presented, it is possible to observe that the Langmuir model presented a better fit $\left(>\mathrm{R}^{2}\right)$ for the coagulant with a saline solution at $1.0 \mathrm{M}$ of $\mathrm{NaCl}$, suggesting homogeneous and monolayer adsorption characterizing a more selective adsorption process, as reported by Mateus et al. (2020). The decay in $\mathrm{R}^{2}$ values when compared with aqueous solution suggests that the mechanisms involved tend to change when saline solution is used to extract the coagulant from Zygia cauliflora (Willd.) Killip. seeds.

However, these models were not found to fit for the coagulant prepared with a saline solution at $5.0 \mathrm{M}$ of $\mathrm{NaCl}$, which presented $\mathrm{R}^{2}$ for the Langmuir model of 0.03 and for the Freundlich model of 0.15. This occurrence indicates that the coagulant obtained from Zygia cauliflora (Willd.) Killip. at higher saline concentrations more probably form a netlike structure followed by turbidity removal through a sweep coagulation mechanism, as previously described (Fahmi et al., 2011). \\ IPABH}




\section{CONCLUSIONS}

This study showed that the concentration of $\mathrm{NaCl}$ slightly influenced the removal of water parameters such as color, turbidity, $\mathrm{UV}_{254}$ compounds, and DOM using the coagulants obtained from Zygia cauliflora (Willd.) Killip. The optimum dosage of coagulant for color and turbidity removal was $2.0 \mathrm{mg} \mathrm{L}^{-1}$ with $1.0 \mathrm{M} \mathrm{NaCl}$, which is very low and removed $21 \%$ of DOM from treated water. The removal of color, turbidity, $\mathrm{UV}_{254}$ compounds, and DOM were $30.4 \%$, $74.5 \%, 70.1 \%$, and $21.5 \%$, respectively, in this optimum dosage.

Furthermore, aqueous solution in concentrations of 3.0 and $4.0 \mathrm{mg} \mathrm{L}^{-1}$ removed $\mathrm{UV}_{254}$ compounds and DOM more efficiently, with values of $74.3 \%$ and $31.7 \%$, respectively.

Moreover, the mechanism for turbidity removal by the coagulants prepared with aqueous solution and with a saline solution at $1.0 \mathrm{M}$ of $\mathrm{NaCl}$ is supposed to be adsorption and charge neutralization, with the adsorption isotherm following the Freundlich model for aqueous solution and the Langmuir model for saline solution at $1.0 \mathrm{M}$ of $\mathrm{NaCl}$. Therefore, the coagulant prepared with a saline solution at $5.0 \mathrm{M}$ of $\mathrm{NaCl}$ tends to form a netlike structure followed by turbidity removal through sweep coagulation mechanism.

According to the data presented, the Zygia cauliflora (Willd.) Killip seed can be used as a natural coagulant and is a good alternative to improve water quality for human supply.

\section{REFERENCES}

APHA; AWWA; WEF. Standard Methods for the examination of water and wastewater. 22nd ed. Washington, 2012. 1496 p.

BONDY, S. C. The neurotoxicity of environmental aluminum is still an issue. $\begin{array}{lllllll}\text { NeuroToxicology, } & \text { v. } & 31, & \text { n. } & 5, & \text { p. } & 575-581,\end{array}$ https://doi.org/10.1016/j.neuro.2010.05.009

BRATSKAYA, S.; SCHWARTZ, S.; CHERVONETSKY, D. Comparative Study of Humic Acids Flocculation with Chitosan Hydrochloride and Chitosan Glutamate. Water Research, v. 38, p. 2955-2961, 2004. https://doi.org/10.1016/j.watres.2004.03.033

DI BERNARDO, L.; DI BERNARDO, A.; CENTURIONE FILHO, P. L. Ensaios de Tratabilidade de Água e Resíduos Gerados em Estações de Tratamento de Água. São Carlos: Rima, 2002.

FAHMI, M. R.; NAJIB, N. W. A.Z.; PING, P. C.; HAMIDIN, N. Mechanism of turbidity and hardness removal in hard water sources by using Moringa oleifera. Journal of Applied Sciences, v. 11, p. 2947-2953, 2011.

FLATEN, T. P. Aluminium as a risk factor in Alzheimer's disease, with emphasis on drinking water. Brain Research Bulletin, v. 55, n. 2, p. 187-196, 2001. https://doi.org/10.1016/S0361-9230(01)00459-2

GAIKWAD, V. T.; MUNAVALLI, G. R. Turbidity Removal by Conventional and Ballasted Coagulation with Natural Coagulants. Applied Water Science, v. 9, 2019. https://doi.org/10.1007/s13201-019-1009-6

KHAN, S.; YAOGUO, W.; XIAOYAN, Z.; JINGTAO, L.; JICHAO, S.; SIHAI, H.; Estimation of concentration of dissolved organic matter from sediment by using uv-visible spectrophotometer. International Journal of Environmental Pollution and Remediation, v. 2, p. 24-29, 2014. https://dx.doi.org/10.11159/ijepr.2014.004 
KUKIC, D. V.; SCIBAN, M. B.; PRODANOVIC, J. M.; TEPIC, A. N.; VASIC, M. A. Extracts of fava bean (Vicia faba L.) seeds as natural coagulants. Ecological Engineering, V. 84, p. 229-232, 2015. https://doi.org/10.1016/j.ecoleng.2015.09.008

LIMA, B. C.; PINGUELO, G. C. B.; VEMASQUI, L. G.; TEIXEIRA, G. G.; SILVA MEDEIROS, F. V. Influência do tempo de mistura lenta no uso de quiabo como floculante aplicado associado ao policloreto de alumínio. Brazilian Journal of Food Research, v. 8, n. 4, p. 13-22, 2017. http://dx.doi.org/10.3895/rebrapa.v8n4.4014

MADRONA, G. S.; SERPELLONI, G. B.; VIEIRA, A. M. S.; NISHI, L.; CARDOSO, K. C.; BERGAMASCO, R. Study of the effect of saline solution on the extraction of the Moringa oleifera seed's active component for water treatment. Water, Air and Soil Pollution, v. 211, n. 1-4, p. 409-415, 2010. https://doi.org/10.1007/s11270-009-0309-0

MALIK, Q. H. Performance of Alum and Assorted Coagulants in Turbidity Removal of Muddy Water. Applied Water Science, v. 8, n. 40, 2018. https://doi.org/10.1007/s13201-018$0662-5$

MATEUS, G. A. P.; SANTOS, T. R. T.; SANCHES, I. S.; SILVA, M. F.; ANDRADE, M. B.; PALUDO, M. P.; GOMES, R. G.; BERGAMASCO, R. Evaluation of a magnetic coagulant based on $\mathrm{Fe} 3 \mathrm{O} 4$ nanoparticles and Moringa oleifera extract on tartrazine removal: coagulation-adsorption and kinetics studies. Environmental Technology, v. 41, p. 1648-1663, 2020. https://doi.org/10.1080/09593330.2018.1543358

NISHI, L.; MADRONA, G. S.; VIEIRA, A. M. S.; BASSETI, F. J.; SILVA, G. F.; BERGAMASCO, R. Coagulação/Floculação com Sementes de Moringa oleifera Lam para Remoção de Cistos de Giardia spp. e Oocistos de Cryptosporidium spp. da água. In: INTERNATIONAL WORKSHOP: ADVANCES IN CLEANER PRODUCTION, 3. May 18-20 2011, São Paulo. Papers[...] São Paulo: UNIP, 2011.

NKURUNZIZA, T.; NDUWAYEZU, J. B.; BANADDA, E. N.; NHAPI, I. The effect of turbidity levels and Moringa oleifera concentration on the effectiveness of coagulation in water treatment. Water Science and Technology, v. 59, n. 8, p. 1551-1558, 2009. https://doi.org/10.2166/wst.2009.155

OLIVEIRA, J. C.; VIEIRA, I. C. G.; ALMEIDA, A. S.; SILVA JUNIOR, C. A. Floristic and Structural Status of Forests in Permanent Preservation Areas of Moju River Basin, Amazon Region. Brazilian Journal of Biology, v. 76, n. 4, 2016. https://doi.org/10.1590/1519-6984.04415

ORGANIZAÇÃO PAN-AMERICANA DA SAÚDE. Água e saúde. Brasília, 2001.

RAMAVANDI, B. Treatment of water turbidity and bacteria by using a coagulant extracted from Plantago ovata. Water Resources and Industry, v. 6, p. 3-50, 2014. https://doi.org/10.1016/j.wri.2014.07.001

RICHTER, C. A. Água: métodos e tecnologia de tratamento. São Paulo: Blucher, 2009.

RICHTER, C. A.; AZEVEDO NETTO, J. M. de. Tratamento de água: tecnologia atualizada. São Paulo: Edgard Blücher, 1991.

SALAZER GÁMEZ, L. L.; LUNA-DEL RISCO, M.; CANO, R. E. S. Comparative study between $M$. oleifera and aluminum sulfate for water treatment: case study Colombia. Environmental Monitoring and Assessment, v. 187, n. 10, 2015. https://doi.org/10.1007/s10661-015-4793-y 
SÁNCHEZ-MARTIN, J.; GHEBREMICHAEL, K.; BELTRÁN-HEREDIA, J. Comparison of single-step and two-step purified coagulants from Moringa oleifera seed for turbidity and DOC removal. Bioresource Technology, v. 101, n. 15, p. 6269-6261, 2010. https://doi.org/10.1016/j.biortech.2010.02.072

SIA, G. B.; VERNASQUI, L. G.; CONSOLIN-FILHO, N.; GONÇALVES, M. S.; SILVAMEDEIROS, F.V. Zinc adsorption from aqueous solution on biosorbent from urban pruning waste. Environmental Technology, v. 41, p. 1-10, 2020. https://doi.org/10.1080/09593330.2020.1803418

TIRADO, D. F.; HERRERA, A. P.; ACEVEDO CORREA, D. Evaluation of the Coagulant Capacity of Starch Obtained from Topocho Pelipita Plantain Clone (Musa abb) for Turbidity and Color Removal in Raw Waters. Revista Internacional de Contaminación Ambiental, v. 33, p. 125-134, 2017. http://dx.doi.org/10.20937/RICA.2017.33.esp01.11

VALVERDE, K. C.; COLDEBELLA, P. F.; SILVA, M. F.; NISHI, L.; BONGIOVANI, M. C.; BERGAMASCO, R. Moringa oleifera Lam. and Its Potential Association with Aluminium Sulphate in the Process of Coagulation/Flocculation and Sedimentation of Surface Water. International Journal of Chemical Engineering, v. 2018, 2018. https://doi.org/10.1155/2018/4342938

ZHOU, T.; XIA, F.; DENG, Y. Removal of Pb(II) from aqueous solutions using waste textiles/poly(acrylic acid) composite synthesized by radical polymerization technique. International Journal of Environmental Science, v. 67; p. 368-377, 2018. https://doi.org/10.1016/j.jes.2017.04.010 